\title{
Tracking Lateglacial and early Holocene environmental change: a palaeolimnological study of sediments at Preluca Ţiganului, NW Romania
}

\section{Angelica FEURDEAN*}

Western University "Vasile Goldiş”, M. Viteazu 26, 440030, Satu Mare, Romania

Quaternary Research Group, Department of Geology, "Babeş-Bolyai” University, Kogălniceanu 1, 400084 Cluj, Romania

Received 20 October 2004; accepted 21 April 2005

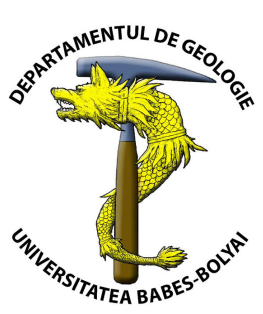

\begin{abstract}
Palaeoecological, palaeohydrological, and paleoenvironmental reconstruction of the Late Glacial and the early Holocene have been performed from sediment accumulated in a small former crater lake, in the Gutâi Mountains, NW Romania. Pollen, lithology, mineral magnetic, and loss-on-ignition analyses in conjunction to radiocarbon dating have been use for this purpose. The data indicates that during the Late Glacial period, vegetation dynamics were likely driven by climatic fluctuations. The climate events during the Late Glacial are well mirrored in local vegetation assemblage development, and past lake level fluctuations. These climatic events recorded in south-eastern Europe, are well correlated with the climate events from the North Western Europe and Greenland ice core stratigraphy.
\end{abstract}

Key words: lake-level fluctuation, local vegetation development, climate, Late Glacial/early Holocene, Preluca Țiganului, Romania.

\section{INTRODUCTION}

The Late glacial environment $(15,000$ - 11,000 cal. yr $\mathrm{BP})$ has been widely studied due to the rapid changes that have occurred within this time framework. Important clues for environmental reconstruction are lake sediments that can be analyzed by a combination of different methods. Among these techniques, pollen and spore analysis is a major tool for vegetation reconstructions, biogeography, palaeoecology, biostratigraphic correlation and past climates. Generally, the vegetation is in equilibrium with the climatic conditions. When the climate changes the vegetation tends to respond according to its physiological limits (Iversen 1954; Ammann et al., 2000; Tinner and Lotter, 2001; Williams et al., 2002). The terrestrial pollen data can be used to describe the history of the upland vegetation, and aquatic and wetland pollen types were used to reconstruct past lake status and peat surface conditions. The succession of aquatic taxa from the littoral zone of the lake towards the center can be used to document local basin dynamics and give an indication of the climate (Hannon, 1999). Supplementary data obtained from lithological and physical parameters are required to distinguish between climatically driven events and local basin infillings that causes changes in the water level (Hannon, 1999). Lithostratigraphy and mineral magnetic parameters (magnetic susceptibility and SIRM) can give information about sediment characteristics, basin morphology, waterlevel fluctuations, and the erosion of sediments from the surrounding slopes (Digerfeldt, 1988; Harrison and Digerfeldt, 1993). The loss on ignition (LOI) was used as an approximate indicator of aquatic productivity, inorganic input, decomposition, and changes in the depositional environment.

Earlier investigations in the Gutâiului Mountains were mainly concerned with the Holocene woodland development (Pop, 1932, 1942, 1960; Lupşa, 1980). The chronology was completely absent and a time framework was established by comparison with the German scheme of Firbas (1949, 1952). In the last decade, a few of these old sites were reinvestigated (including the present site) using modern methods in order to reconstruct the various aspects (vegetation, ecology, lake level fluctuation, chronology, and climate) of the Late Glacial and Holocene environment. Furthermore, correlations between Romanian palaeoenvironment and other well-dated sequences from north-western Europe can now be performed (Wohlfarth et al., 2001; Feurdean et al., 2001, 2004; Björkman et al., 2002, 2003).

The present paper is concerned with different aspects of environmental history from the Late Glacial to the early Holocene, based on pollen analysis, LOI, magnetic measurements, lithological analysis, and AMS ${ }^{14} \mathrm{C}$ measurements of the sediment sequence obtained from the Gutâiului Mountains, NW Romania.

\section{STUDY AREA}

The study site, Preluca Țiganului (N 4748'83'; E $\left.23^{\circ} 31^{\prime} 91^{\prime \prime}\right)$, is situated on the western flank of the volcanic Gutâiului Mountains, Eastern Carpathians, at an altitude of ca. $730 \mathrm{~m}$. a.s.l (Fig. 1). The site is a former crater with a total surface of 1 ha. The glaciers did not cover the region (Bălteanu et al., 1998), but the area may have been subject 
to periglacial processes. The small basin size allows us to distinguish between local and regional vegetation (Jacobson and Bradshaw, 1981; Sugita, 1994). It is a topographically closed basin where the hydrological balance is controlled by $\mathrm{T}$ (temperature) /P (precipitation) /E (evaporation) changes and can be tentatively used for the reconstruction of lake level fluctuations, hence the climatic conditions.

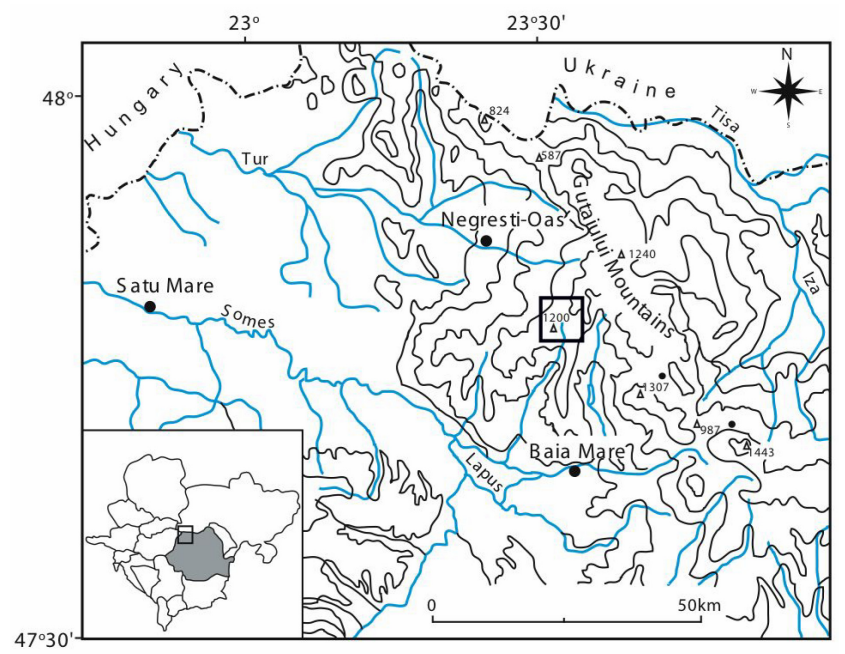

Fig. 1. Map over the north-western Romania and location of the investigated site in the Gutâiului Mountains

The climate of the region is continental temperate. The mean annual precipitation shows a significant altitudinal gradient and ranges from ca. $700 \mathrm{~mm}$ to ca. 1200-1400 $\mathrm{mm}$ in the higher elevations. Mean annual temperature is approximately $8^{\circ} \mathrm{C}$ and the mean winter and summer temperatures are $-3^{\circ} \mathrm{C}$ and $12-13^{\circ} \mathrm{C}$, respectively. The site lies within the beech (Fagus sylvatica) forest belt in which the rare Betula verrucosa, Acer pseudoplatanus, Corylus avellana, Carpinus betulus, and Tilia cordata can be found (Istvan et al., 1990). On the higher peaks a very narrow mixed Picea-Fagus forest belt exist. The site is a eumesotrophic peat bog with vegetation composed of grasses, sedges, herbs, and mosses (Lupşa, 1980).

\section{MATERIAL AND METHODS}

\section{Fieldwork}

Fieldwork took place in May 1999, and coring was performed with a Russian sampler $(1 \mathrm{~m}$ length and $5 \mathrm{~cm}$ diameter). Overlapping cores were collected from the central part of the peat bog. The sediments were preliminary described in the field. Laboratory work was performed at the Department of Quaternary Geology in Lund, Sweden.

\section{Laboratory analyses}

\section{Pollen analysis}

The resolution of the sample for pollen analysis varied between $2,5-\mathrm{cm}$ and $4-\mathrm{cm}$ interval. The chemical preparation for pollen analysis follows the standard methods of Berglund and Ralska-Jasiewiczowa (1986) and Moore et al. (1991). Lycopodium tablets of known concentration were added in order to calculate total pollen concentration. Pollen and spores identification was based on the keys and illustrations of Moore et al. (1991), Reille (1992) and by comparison with reference collections at the Department of
Geology, Lund University. An average of 500 pollen grains, excluding aquatic pollen and spores, were counted at each level and comprised around 20-25 pollen taxon. Percentages of terrestrial pollen were calculated on the basis of their total sum, excluding aquatic pollen and spores. Percentages of spores and aquatic pollen types were calculated on the basis of the total sum including terrestrial spores and aquatic pollen types. The pollen diagram was constructed with the TILIA computer program (Grimm, 1992).

\section{Loss-on-ignition}

The organic matter content of the cores was estimated by loss on ignition (Bengtesson and Enell, 1986). The cores were sub-sampled and analyses at $2 \mathrm{~cm}$ interval for LOI. The samples were placed in crucibles with a known weight, dried for ca. 6 hours at $100^{\circ} \mathrm{C}$ (to loose the water content), cooled and weighed. The samples were then ashed at $550^{\circ} \mathrm{C}$ for 3 hours, cooled, and re-weighed. LOI is expressed as a percentage of the weight of the dried sample.

\section{Magnetic measurements}

The samples were dried at $40^{\circ} \mathrm{C}$, in order to calculate magnetic susceptibility and Saturation Isothermal Remanent Magnetization (SIRM). Magnetic susceptibility was measured in a low magnetic field of $0.1 \mathrm{mT}$ and the mass specific units were calculated and expressed as $\mu \mathrm{m}^{3} \mathrm{~kg}^{-1}$. SIRM was induced in a strong magnetic field of 1 Tesla and the resulting remnant magnetization was measured with a Molspin Spinner Magnetometer. Mass specific units were calculated as $\mathrm{mAm}^{2} \mathrm{~kg}^{-1}$ (Walden et al., 1999).

\section{Radiocarbon dating}

AMS ${ }^{14} \mathrm{C}$ measurements were performed on terrestrial plant macrofossils and peat. Twelve samples were radiocarbon dated by means of AMS at the University of Uppsala, Sweden.

\section{RESULTS AND INTERPRETATION}

\section{Lithostratigraphy, content of organic matter, mineral magnetic measurements}

Based on sediment description, 10 lithological units were identified (Table 1). The measurements of magnetic susceptibility, SIRM and organic matter content are presented in Fig. 2. Transitions between individual units are gradual with one exception at $8.95 \mathrm{~m}$, where a distinct beige horizon with sharp layer boundary appears within the dark brown peat. The gradual layer boundary indicates a continuous deposition in the basin, whereas a sharp layer boundary may indicate rapid change in depositional environment or hiatus.

The detritus gyttja (unit 1a, b, and c; 9.90-9.59 m) deposited between 14,400 and 14,300 cal. yr BP show low values of mineral magnetic parameters. The $\mathrm{OM}$ values reach $40-70 \%$ (Table 1, Fig. 2). The mineral magnetic susceptibility and SIRM increase distinctly while the OM values decrease to $20 \%$ at the transition to the clay gyttja (unit 2, 9.59-9.49 m) deposited about 14,300 cal. yr BP.

Approximately 14,250 to 14,150 cal. yr BP the peaty gyttja (unit 3, $9.49-9.33 \mathrm{~m}$ ) accumulated with lower mineral magnetic values and higher OM percentages. In the 
Table 1. Lithostratigraphic description of the Preluca Tiganului sediment cores $(L B=$ lower boundary; $s=$ sharp; $g=$ gradual $)$.

\begin{tabular}{|c|c|c|}
\hline Units & Depth (m) & Description \\
\hline 10 & $6.13-4.00$ & Fen peat, gLB \\
\hline 9 & $6.13-8.70$ & Dark brown carr peat, gLB \\
\hline 8 & $8.70-8.78$ & Brown peaty gyttja, gLB \\
\hline 7 & $8.78-8.89$ & Dark brown gyttja peat, gLB \\
\hline 6 & $8.89-9.10$ & $\begin{array}{l}\text { Dark brown peat, gLB, at } 8.95 \text { beige distinct layer } \\
\text { with sharp boundary }\end{array}$ \\
\hline 5 & $9.10-9.14$ & Dark brown gyttja peat, rgLB \\
\hline 4 & $9.14-9.33$ & $\begin{array}{l}\text { Greyish clay gyttja with coarse wood fragments, } \\
\text { gLB }\end{array}$ \\
\hline 3 & $9.33-9.49$ & Dark brown peaty gyttja \\
\hline 2 & $9.49-9.59$ & $\begin{array}{l}\text { Greyish brown clay gyttja with some organic } \\
\text { horizon, gLB }\end{array}$ \\
\hline $1 \mathrm{c}$ & $9.59-9.68$ & $\begin{array}{l}\text { Greyish brown fine detritus gyttja with wood } \\
\text { peaces, gLB }\end{array}$ \\
\hline $1 b$ & $9.68-9.84$ & $\begin{array}{l}\text { Dark brow coarse detritus gyttja, with } 1 \mathrm{~cm} \text { large } \\
\text { wood fragments, gLB }\end{array}$ \\
\hline $1 \mathrm{a}$ & $9.84-9.90$ & Dark brown fine detritus gyttja, gLB \\
\hline
\end{tabular}

clay gyttja (unit 4, 9.33-9.14 m) around 14,150 and 14,100 cal. yr BP, mineral magnetic parameters attain their maximum values and $\mathrm{OM}$ decreased to about $20 \%$. Between 14,100 and 14,000 cal. yr BP, gyttja peat (unit 5, 9.14-9.10 $\mathrm{m}$ ) and peat (unit $6,9.10-8.89 \mathrm{~m}$,) were formed.

Mineral magnetic parameters decline sharply and $\mathrm{OM}$ values increase abruptly to about $70 \%$. Increasing mineral magnetic and declining $\mathrm{OM}$ values characterize the gyttja peat (unit $7,8.89-8.78 \mathrm{~m}$ ) and peaty gyttja (unit $8,8.78-$ $8.70 \mathrm{~m}$ ) between 14,000 and 13,900 cal. yr BP. The transitions to the overlying carr peat (unit 9, 8.70-6.13 m) and fen peat (unit 10,6.13 - $4.00 \mathrm{~m}$ ) have an age of approximately 13,900 and 10,750 cal. yr BP, respectively. OM values rise to around $90 \%$ in unit 9 , but decrease to around $65 \%$ in unit 10 .

\section{Chronology}

The obtained AMS radiocarbon dates are presented in Table 2. These dates were converted into calendar years BP using the calibration curve of Stuiver et al. (1998) and the OxCal v3.5 program (Bronk Ramsey, 1995).

The ages presented in the text refer to the calendar years BP and the age depth model is shown in detail in Björkman et al. (2002).

Table 2. $A M S^{14} C$ dates from Preluca Tiganului. Calibrated years $B P$ were obtained through calibration with the Oxcal v3,5 program (Bronk Ramsey, 1995).

\begin{tabular}{|c|c|c|c|c|}
\hline Lab.no & Depth (m) & Dated material & ${ }^{14} \mathrm{C}$ age $\mathrm{BP}$ & Calibrated \\
\hline & & & & years BP \\
\hline Ua-16341 & $5.25-5.205$ & $\begin{array}{l}\text { charcoal, wood, } \\
\text { bark }\end{array}$ & $8,565 \pm 90$ & $9,900-9,400$ \\
\hline Ua-16340 & $6.07-6.03$ & wood & $9,185 \pm 100$ & $10,640-10,610$ \\
\hline Ua-16339 & $6.34-6.29$ & wood & $9,680 \pm 90$ & $11,250-10,700$ \\
\hline Ua-16338 & $6.43-6.385$ & wood & $9,685 \pm 95$ & $11,250-10,700$ \\
\hline Ua-16337 & $6.725-6.68$ & peat (washed) & $10,240 \pm 90$ & $11,750-11,350$ \\
\hline Ua-16336 & $7.09-7.045$ & wood & $10,265 \pm 115$ & $12,850-11,350$ \\
\hline Ua-16335 & $7.36-7.325$ & peat (washed) & $10,190 \pm 110$ & $12,750-11,250$ \\
\hline Ua-16334 & $8.285-8.24$ & $\begin{array}{l}\text { Picea needles, } \\
\text { bark, wood }\end{array}$ & $11,515 \pm 115$ & $13,850-13,150$ \\
\hline Ua-16333 & $8.73-8.70$ & twigs & $11,950 \pm 125$ & $14,350-13,550$ \\
\hline Ua-16332 & $9.19-9.14$ & $\begin{array}{l}\text { Picea needles, } \\
\text { cone }\end{array}$ & $12,065 \pm 115$ & $14,350-13,800$ \\
\hline Ua-16331 & $9.45-9.40$ & Pinus needles & $12,230 \pm 105$ & $14,450-14,050$ \\
\hline Ua-16330 & $9.905-9.85$ & wood & $12,250 \pm 105$ & $14,450-14,050$ \\
\hline
\end{tabular}

\section{Pollen stratigraphy}

The percentage pollen diagram contains all identified pollen and spores taxa plotted on a linear depth scale
(Fig. 3). Radiocarbon dates and the stratigraphy are shown on the left-hand side of the diagram. To facilitate the description and interpretation of the pollen diagram, eight local pollen assemblages zones (LPAZ 1-8) have been established visually (Fig. 3). A description of the pollen zones is presented below:

P1 Pinus - Poaceae - Ranunculaceae 14,450-14,150 cal. yr BP $(9.32-9.89 \mathrm{~m})$

The pollen assemblage is dominated by Pinus $(55-80 \%)$. Betula is present by lower values, while Picea and Alnus with only scattered pollen grains. The shrubs such as Juniperus and Salix are recognized with scarce pollen grains. The herbaceous pollen values reach $40 \%$, and are mostly represented by Poaceae, Cyperaceae, Ranunculaceae undiff., Artemisia, Filipendula, Thalictrum, Valeriana officinalis, Galium-type, and Chenopodiaceae.

\section{P2 Pinus - Betula - Poaceae 14,150-14,050 cal. yr BP $(9.08-9.32 \mathrm{~m})$}

Pinus reached its highest values in this profile. Betula pollen percentages have increased strongly and show a peak of $50 \%$ in the upper half of the zone. Parallel pollen percentages of all shrub and herbs mentioned above, particularly wetland taxa, have decreased.

P3 Pinus - Poaceae - Ranunculaceae - Artemisia 14,050-13,850 cal. yr BP $(8.60-9.08 \mathrm{~m})$

Pollen frequencies for Betula have been strongly reduced, while pollen values for Pinus remained high. The presence of Picea and Ulmus are indicated only by scattered pollen grains. Percentages of herbaceous pollen, particularly of wetland taxa (Poaceae, Cyperaceae, Ranunculaceae undiff., Filipendula, Valeriana officinalis, and Thalictrum) and of Artemisia show increasing trends.

P4 Pinus - Picea - Betula 13,850-12,900 cal. yr BP $(8.60-8.00 \mathrm{~m})$

Pollen values for Pinus gradually decrease to the end of this zone $(35-70 \%)$, while pollen percentages of Picea, Betula, and Alnus have strongly increased. The pollen frequencies of wetland indicators (Ranunculaceae undiff., Ranunculus-type, Cyperaceae, Menyanthes, Mentha-type, Potentila-type, Utricularia, and Potamogeton) and spores of Polypodiaceae undiff., Equisetum, and Sphagnum have a major increase.

P5 Pinus - Artemisia - Cyperaceae - Picea 12,90012,600 cal. yr BP $(7.79-8.00 \mathrm{~m})$

The AP values (Picea, Betula, and Alnus) have strongly decreased and display a total value of $50 \%$. In parallel, a sharp increase of pollen values of herbaceous taxa, in particular Artemisia (10-25\%), Cyperaceae (10-20\%), Chenopodiaceae, and Valeriana officinalis is recorded. Pollen percentages of aquatic plant (Menyanthes, Utricularia, and Potamogeton), and spores of Sphagnum disappeared, along with a distinct reduction values of Equisetum.

P6 Pinus - Artemisia- Betula 11,600-11,500 cal. yr BP $(6.80-7.79 \mathrm{~m})$

The herbaceous pollen types reached the highest values, particularly for Artemisia (10-25\%). For trees, Pinus (25-75\%) occurs with high pollen percentages, while Picea 
has been reduced. Noteworthy is the significant presence of Juniperus, Salix, Helianthemum, Rumex, Centaurea, and Ephedra. Spores of wetland indicators Polypodiaceae undiff., Equisetum, and pollen of Potamogeton are also present with low values.

P7 Ulmus - Picea - Pinus 11,500-10,700 cal. yr BP $(6.13-6.80 \mathrm{~m})$

The beginning of this zone is characterized by a gradually decreased of Pinus, while Betula, Alnus, and Picea have considerably increased. Also present, are the pollen of Quercus, Fraxinus, Corylus, Tilia, and Ulmus, but only with scattered pollen grains. Recorded at $6.49 \mathrm{~m}$ is a sharp increase of pollen frequencies of Ulmus (25-45\%) and Picea, simultaneously, there is a rapid reduction of Artemisia, Chenopodiaceae, and Cyperaceae. Pollen values of wetland taxa (Menyanthes, Filipendula, Thalictrum, and Galium-type), and spore frequencies of Polypodiaceae undiff., and Equisetum have strongly increased.

P8 Ulmus - Filipendula - Picea 10,700-10,600 cal. yr $B P(5.64-6.13 \mathrm{~m})$

This zone is characterized by high pollen percentage for Ulmus (40\%) and Picea. Pollen values of Quercus, Tilia, Fraxinus, and Corylus have increased. Except for that of wetland taxa, the other herbaceous pollen values have been reduced.

\section{DISCUSSION}

\section{4,400 - 14,050 cal. yr BP}

The upland vegetation was an open forest type, composed primarily of Pinus, Betula, and scattered Picea individuals (P1, 2; Fig. 3). The open sections of the landscape were dominated by shrubs (Salix, Juniperus), and herbs, in particular the cold, dry indicators (Artemisia, Chenopodiaceae, Helianthemum, Asteraceae Tubuliflorae, Asteraceae Liguliflorae, and Poaceae). During the last 100 years of this period, the forest became denser as suggested by higher values of total pollen concentration and the tree pollen sum (P3, Fig. 3).

During this period, the site was a lake. Different types of gyttja were deposited, indicating that the lake seems to have experienced episodic oscillation of water, organic production, and minerogenic input. Therefore, transition from fine detritus gyttja (unit 1) to coarse detritus gyttja (unit 2) could indicate a phase during which the lake level was lowered (Fig. 2, Table 1). Later, coarse detritus gyttja graded upward into fine detritus gyttja (unit 3), which may indicate a rise of the lake water level and an increase of runoff. The rise in water level is also reflected by high values of mineral magnetic parameters and low organic matter content. The minerogenic material could have been transported and accumulated in the lake by a stream that drained the slopes around the basin catchment area (Ghergari and Onac, 2001). Above the fine detritus gyttja, the sediments change into a peaty gyttja indicating a lowering of the lake level. Along the lake shore, sedges (Cyperaceae) and other wet-loving plant species such as Ranunculaceae, Filipendula, Galium - type, Valeriana officinalis, and trees such as Betula, Alnus, and Salix have constituted the rim vegetation communities (P1, P2, Fig. 3). The advancing of this marginal flora towards the central part of the basin indicates that the lake water level was very low. Between 14,150 and 14,100 cal. yr BP, deposition of clay gyttja with high values for mineral magnetic parameters

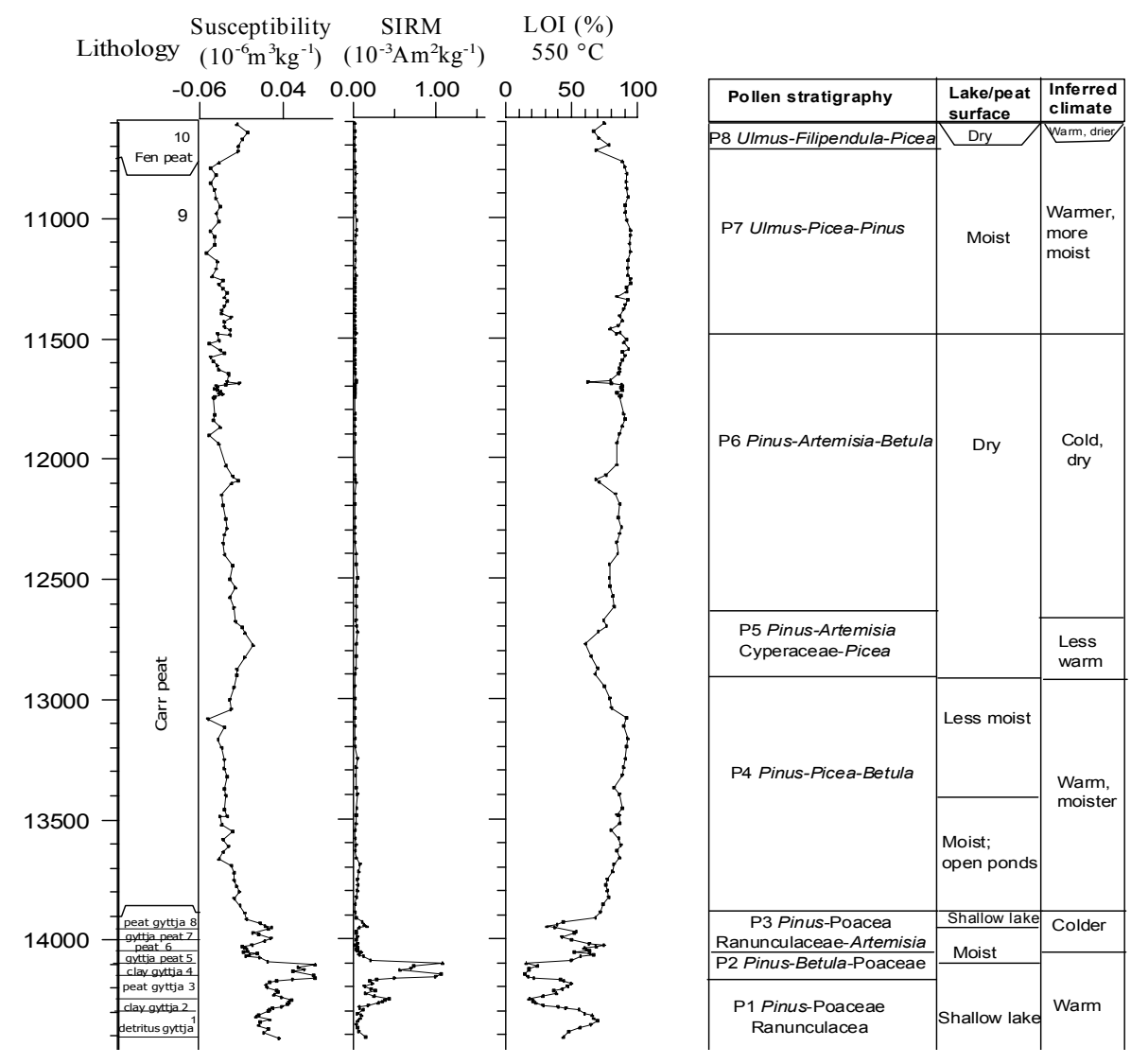

Fig. 2. Lithology, LOI, mineral magnetic measurement, pollen assemblage zones; inferred past lake status/peat development and climate change during the Late Glacial and beginning of the Holocene from Preluca Tiganului sediment sequence. 


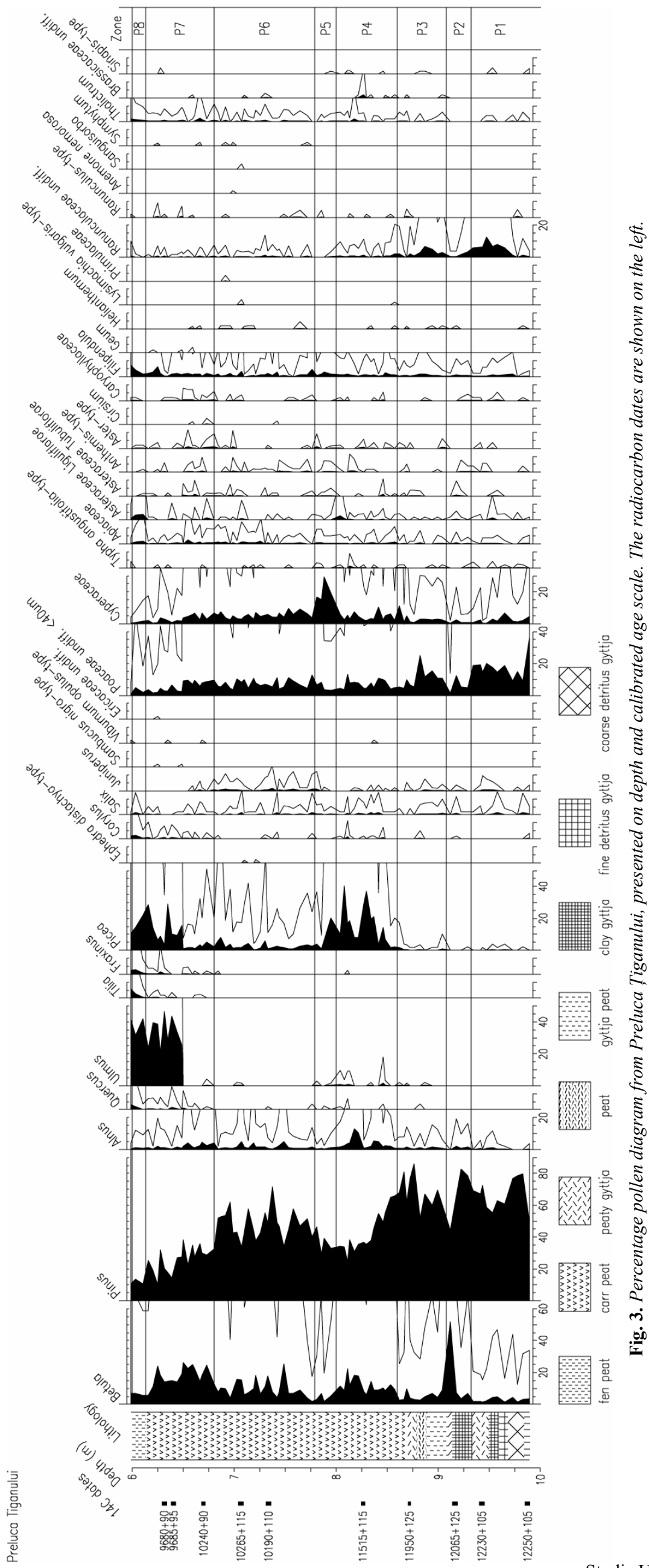

Studia UBB, Geologia, 2005, 50 (1-2), 3 - 11 

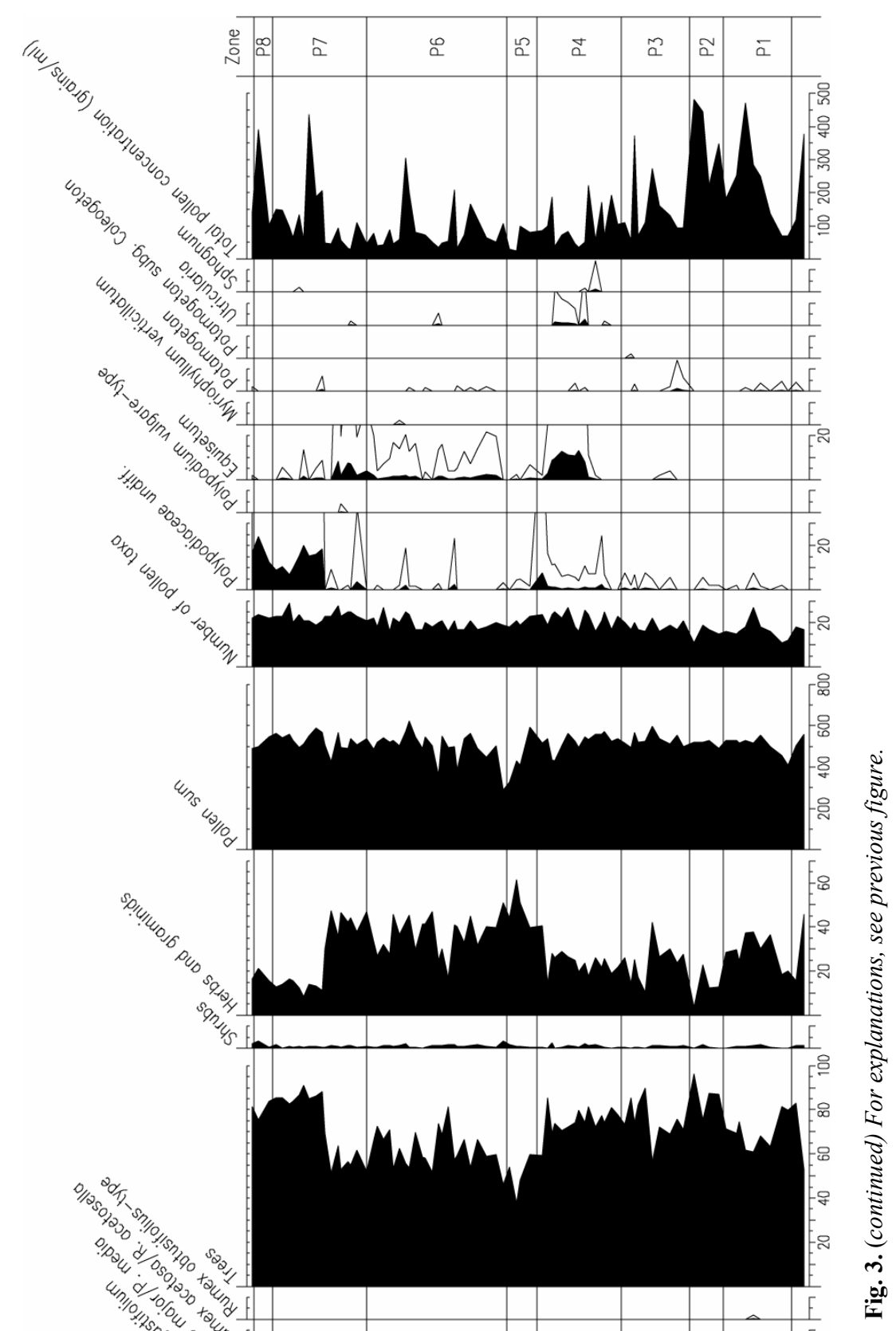

Studia UBB, Geologia, 2005, 50 (1-2), 3 - 11

(u) पldə0 
indicates that lake level rose and probably caused erosion of the shoreline (Fig. 2). Furthermore, the data supporting of deeper lake water is the retraction of marginal vegetation from the central part of the lake. Low values of organic content could reflect low organic production and erosion. At the end of this period, clay gyttja grades into gyttja peat along with the re-advancement of marginal vegetation toward the central part of the lake, suggesting a new drop of the water level in the lake.

Corroborating the data set with the radiocarbon dates, we assumed this period was evolving under warmer climate condition at the beginning of the Late Glacial.

\section{4,100 - 13,800 cal. yr BP}

During this period, greater values of herbaceous pollen taxa (Artemisia, Poaceae, Chenopodiaceae, and Cyperaceae), indicate a more open landscape compared to the previous time interval (P4, Fig. 3). The AP values and total pollen concentrations have diminished considerably, suggesting a lower forest density cover around the lake (Fig. 3).

Palynological data shows a strong relationship with lithological and sedimentological data. The deposition of peat sediment indicates a temporary water body in the basin, rapidly followed by rising lake levels and the accumulation of gyttja peat and peat gyttja. Flora such as Utricularia, Potamogeton, Menyanthes, and Equisetum, were abundant in open water; whereas Ranunculaceae undiff., Ranunculustype, Cyperaceae, Mentha-type, Potentila-type, Sphagnum, and Polypodiaceae undiff., were common on the basin surface and close to the margin. Low organic matter content and higher values of mineral parameters between 14,000 and 13,900 cal. yr BP, indicates an increase of erosional processes (Fig. 2).

The expansion of more open vegetation indicators and an initial low lake level may be the result of cold climatic conditions with a low evaporation ratio that led to a rise in lake water level. This could be synchronous with GI 1d substadial, in the GRIP ice core stratigraphy (Björck et al., 1998).

\section{3,800 - 12,900 cal. yr BP}

The pollen assemblage indicates the expansion of the boreal forest type with Picea, Betula, Pinus, Salix, Alnus, and Ulmus (P4, Fig. 3). The plant macro-remains studies confirm the local spreading of several trees such as Picea, Pinus cembra, P mugo, Betula sp., Salix sp., and Larix decidua (Wohlfarth et al., 2001; Feurdean and Bennike, 2004).

The accumulation of carr peat sediments at the beginning of this period indicates the final infilling of the lake. A minimal lake water level or small ponds over peat bog surface must have occurred as reflected by the greatest representation of aquatic flora (Equisetum, Utricularia, Potamogeton, and Menynathes). The abundance and high diversity of wetland and aquatic flora along with higher values of organic matter content of the sediments indicates an increase in water temperatures. The effect of the expansion of coniferous and cold deciduous forest in the lake catchment areas is the development of forest soils that account for higher organic content of the sediments (Fig. 2). The evaporation ratio must have been high, allowing for the great expansion of marginal flora towards the center of the lake basin. This could correspond with warmer episodes GI 1c-1a in the GRIP ice core, which is similar with Alleröd interstadial in northwestern Europe.

\section{2,900 - 11,500 cal. yr BP}

The progressive development of open vegetation communities is indicated by high values of pollen herbs including Artemisia, Poaceae, Chenopodiaceae, Asteraceae Tubuliflorae, Asteraceae Liguliflorae, and Helianthemum. Shrubs (Juniperus, Salix) and patches of trees (Pinus, Betula, and Picea) also existed.

During this period, the site was a carr peat. The value of organic matter decreased to $60 \%$ along with a slight increase of SIRM and magnetic susceptibility, suggesting that the slope erosion still took place under a diminished tree cover (Fig. 2). The abundant presence of pollen percentages of Cyperaceae, Ranunculaceae undiff., Filipendula and Valeriana indicate the development of a sedge community over the peat bog surface. Parallel, distinct reduction of aquatic abundance and diversity could point to a dryer peat surface condition and lower temperature. Dominance of pollen of Poaceae from around 12,500 cal. yr BP indicates expansion of a nutrient rich, moist meadow over the basin surface. This episode may correspond to Younger Dryas stadial or to the GS-1 event in the GRIP stratigraphy.

\section{1,500 - 10,700 cal yr BP / beginning of the Holocene}

The climate warming approximately 11,500 years ago was evident in the lithology, biostratigraphy and sedimentology of Preluca Țiganului. The terrestrial pollen assemblages show that open vegetation was quickly replaced by forest vegetation, first with Betula and Pinus, following by the rapid expansion of Ulmus and Picea (Björkman et al., 2002, Feurdean, 2004). The arrival of Quercus, Tilia, and Fraxinus probably occurred around 11,250 cal. yr BP; however, they did not expand until around 10,700 cal. yr BP. Relatively dense forest at the beginning of the Holocene led to a stabilization of the soils and reduction of erosion in the basin catchment. This is indicated by increasing proportions of organic matter and decreasing values of mineral magnetic parameters (Fig. 2). Soil development continued along with the extension of the deciduous forest.

A close relationship existed between terrestrial vegetation, wetland and aquatic flora. The expansion of Cyperaceae, Menyanthes, Valeriana officinalis, Thalictrum, Apiaceae, Polypodiaceae undiff., Galium - type, and Equisetum could be the response to the higher temperature and wetter peat surface conditions during the early Holocene. The subsequent reduction of pollen of these taxa at ca. 10,700 cal. yr BP indicates a gradual change towards drier peat surface conditions. Higher temperature with high evaporation ratio could have led to this drier climate.

\section{CONCLUSIONS}

Preluca T,iganului crater lake is a particular suitable study site for both limnological and terrestrial changes. The high ratio of sedimentation associated with a secure chronological control allows high temporal resolution of the environmental changes during the Late Glacial and beginning of Holocene. 
Relatively stable environmental conditions characterized the beginning of the Late Glacial as revealed by the formation of open forests with Pinus and Betula, and high values of organic matter.

Between 14,100 and 13,800 cal. yr BP, this succession was interrupted by a short episode of climatic cooling with low evaporation ratio conditions inferred from terrestrial, wetland pollen assemblage, and lithology. The forest became reduce to stands of Pinus and Betula.

Warm and moist climatic conditions were inferred between 13,800 and 13,400 cal. yr BP, followed by a decrease in humidity from ca. 13,400 cal. yr BP. This condition led to a rapid expansion of coniferous forests mixed with cold deciduous trees, soil stabilization, and reduction of minerogenic in wash into the lake.

Cooler and drier conditions between 12,900 and 11,500 cal. yr BP are inferred from the recurrence of an open landscape with only Betula, Larix, Salix, and Pinus scattered trees. The lithological composition did not change, but mineogenic input is evidenced by increase in mineral magnetic parameters.

An increase in diversity and abundance of wetland pollen indicators around 11,800 cal. yr BP (most pronounced at $11,500 \mathrm{cal}$. yr BP) reflects higher water temperatures and increased aquatic productivity. At 11,500 cal. yr BP, along with aquatic pollen, terrestrial pollen shows a rapid reforestation with Pinus, Betula, Larix, Populus, and Picea. The reconstruction of climatic conditions for the early Holocene indicates it was warm and wet.

Acknowledgements. Many thanks to colleagues at the Dept. of Physical Geography and Quaternary Geology, Stockholm University and Quaternary Research Group, Babeş-Bolyai University for stimulating discussion on this manuscript. Joe Kearns is greatly acknowledged for English correction.

\section{R E F E R E N C E S}

Ammann, B., Birks, H.J.B., Brooks, S.J., Eicher, U., von Grafenstein, U., Hofmann, W., Lemdahl, G., Schwander, J., Tobolski, K., Wick, L. 2000, Quantification of biotic response to rapid climatic changes around the Younger Dryas-a synthesis. Palaeogeography, Palaeoclimatology, Palaeoecology, 159: 313-347.

Balteanu, D., Ielenicz, M., Popescu, N. 1998, Geomorphology of the Romanian Carpathians. New trends and evolutions. Studia Geomorphologica Carpatho - Balcanica, 32: 89-109.

Bengtsson, L., Enell, M. 1986, Chemical analysis. In Handbook of Holocene Palaeoecology and Palaeohydrology (Berglund, B.E., Ed.), Chichester: John Wiley \& Sons, 423-454.

Berglund, B.E., Ralska-Jasiewiczowa, M., 1986. Pollen analysis and pollen diagrams. In Handbook of Holocene Palaeoecology and Palaeohydrology (Berglund, B.E., Ed.), Chichester: John Wiley \& Sons, 455-484.

Björck, S., Walker, M.J.C., Cwynar, L.C., Johnsen, S., Knudsen, K.L., Lowe, J.J., Wohlfarth, B., INTIMATE members 1998, An event stratigraphy for the Last Termination in the North Atlantic region based on the Greenland ice-core record: a proposal by the INTIMATE group. Journal of Quaternary Science, 13: 283-292.
Björkman, L., Feurdean, A., Cinthio, K., Wohlfarth, B., Possnert, G. 2002, Lateglacial and early Holocene vegetation development in the Gutâiului Mountains, NW Romania. Quaternary Science Reviews, 21: 1039-1059.

Björkman, L., Feurdean, A., Wohlfarth, B. 2003, Lateglacial and Holocene forest dynamics at Steregoiu in the Gutâiului Mountains, NW Romania. Review of Paleobotany and Palinology, 124: 79-111.

Digerfeldt, G. 1988, Reconstruction and regional correlation of Holocene lake level fluctuation in Lake Bysjon, South Sweden. Boreas, 17: 165-182.

Firbas, F. 1949, Spät- und nacheiszeitliche Waldgeschichte Mitteleuropas nördlich der Alpen, Band I. Fischer, Jena, 480 pp.

Firbas, F., 1952. Spät- und nacheiszeitliche Waldgeschichte Mitteleuropas nördlich der Alpen, Band II. Fischer, Jena, $256 \mathrm{pp}$.

Feurdean, A., Bjorkman, L., Wohlfarth, B. 2001, Paleoecological reconstruction of the Late Glacial and Holocene based on multidisciplinary studies at Steregoiu site (Gutai Mts., NW Romania). Studia Universitatis Babes-Bolyai, Geologia, XLVI (2): 125-140.

Feurdean, A. 2004, Palaeoenvironment in Romania during last 15,000 years. $\mathrm{PhD}$ thesis in Quaternary Geology, No 3. Department of Physical Geography and Quaternary Geology, Stockholm University, 128 pp.

Feurdean, A., Bennike, O. 2004, Late Quaternary palaeoecological and palaeoclimatological reconstruction in the Gutâiului Mountains, NW Romania. Journal of Quaternary Science, 19: 809-827.

Grimm, E.C. 1992, Tilia and Tilia-graph: Pollen spreadsheet and graphics programs. Programs and Abstracts, 8th International Palynological Congress, Aix-en-Provence, September 6-12, 1992, pp. 56.

Ghergari, L., Onac, B.P. 2001, Late Quaternary palaeoclimate reconstruction based on clay minerals assemblage from Preluca Țiganului (Gutâi Mountains, Romania). Studia Universitatis Babes-Bolyai, Geologia, XLVI (1): 15-28.

Hannon, G. 1999, The use of plant macrofossils and pollen in the palaeoecological reconstruction of vegetation. $\mathrm{PhD}$ thesis SILVESTRIA 106. Swedish University of Agriculture.

Harrison, S.P., Digerfeldt, G. 1993, European lakes as palaeohydrological and palaeoclimatic indicators. Quaternary Science Reviews, 12: 233-248.

Jacobson, G.L., Bradshaw, R.H.W. 1981, The selection of sites for paleovegetational studies. Quaternary Research, $16,80-96$.

Istvan, D., Popescu, S., Pop, I., 1990. Muntii Gutâi. Sport Turism, Bucureşti, 149 pp.

Iversen, J. 1954, The Late-glacial flora of Denmark and its relation to climate and soil. Danmarks Geologiske Undersogelse Arbøg, 2: 87-119.

Lupşa, V. 1980, Evoluția postglaciară a ecosistemelor forestiere din "Țara Oaşului" (Jud. Satu Mare). Contribuții Botanice, 5: 63-68.

Moore, P., Webb J.A., Collinson, M.E. 1991, Pollen analysis, $2^{\text {nd }}$ ed. Blackwell Scientific Publications, Oxford.

Pop, E. 1932, Contribuții la istoria vegetației cuaternare din Transilvania. Bul. Grad. Bot. Cluj, 12: 29-102.

Pop, E. 1942, Contribuţii la istoria pădurilor din nordul Transilvaniei. Bul. Grad. Bot. Cluj, 9, 3-4: 81-210. 
Pop, E. 1960, Mlaştinile de turbă din R.P.R. Editura Academiei Române, Bucureşti.

Reille, M. 1992, Pollen et spores d'Europe et d'Afrique du nord. Laboratoire de botanique historique et palynologie, Marseille, $520 \mathrm{pp}$.

Stuiver, M., Reimer, P.J., Bard, E., Beck, J.W., Burr, G.S., Hughen, K.A., Kromer, B., McCormac, G., van der Plicht, J., Spurk, M. 1998, INTCAL98 Radiocarbon age calibration, 24,000-0 cal. BP. Radiocarbon, 40: 1041-1083.

Sugita, S. 1994, Pollen representation of vegetation in Quaternary sediments: theory and method in patchvegetation. Journal of Ecology, 82: 881-897.

Tinner, W., Lotter, A.F. 2001, Central European vegetation response to abrupt climate change at $8.2 \mathrm{ka}$. Geology, 29: 551-554.

Walden, J., Oldfield, F., Smith, J.P. 1999, Environmental Magnetism: a practical guide. Technical Guide, No. 6, Quaternary Research Association, London, pp. 35-88.

Williams, J.W., Post, D.M., Cwynar, L.C., Lotter, A.F., Levesque, A.J. 2002, Rapid and widespread vegetation responses to past climate change in the North Atlantic region. Geology, 11: 971-974.

Wohlfarth, B., Hannon, G., Feurdean, A., Ghergari, L., Onac, B.P., Possnert, G. 2001, Reconstruction of climatic and environmental changes in NW Romania during the early part of the last deglaciation $(15,000-13,600$ cal years BP). Quaternary Science Reviews, 20: 1897-1914. 